\title{
GENERA KARANG KERAS DI PULAU BARRANG LOMPO DAN BONE BATANG BERDASARKAN METODE IDENTIFIKASI CORAL FINDER
}

\section{HARD CORAL GENERA IN BARRANGLOMPO AND BONE BATANG ISLAND BASED ON CORAL FINDER IDENTIFICATION METHOD}

\author{
Wahyulfatwatul UAS, Magdalena Litaay, D. Priosambodo, Willem Moka
}

Departemen Biologi, FMIPA, Universitas Hasanuddin, Makassar.

email : Wahyulmlh@gmail.com

\begin{abstract}
Abstrak
Penelitian tentang "Genera Karang Keras Di Pulau Barranglompo Dan Bonebatang Berdasarkan Metode Identifikasi Coral Finder" telah dilakukan pada bulan Januari hingga April 2016. Penelitian ini bertujuan mengetahui variasi genera karang keras yang ada di Pulau Barranglompo dan Pulau Bonebatang. Pengambilan data dilakukan dengan metode "Line Intercept Transect (LIT)", di sisi selatan, barat dan utara masing - masing pada kedalaman 3 dan $10 \mathrm{~m}$. Penentuan genera karang dilakukan berdasarkan metode identifikasi Coral Finder. Hasil penelitian menunjukkan bahwa pada kedalaman $3 \mathrm{~m}$ genera karang yang ditemukan di Pulau Bonebatang (31 genera) lebih banyak dibandingkan dengan Pulau Barranglompo (24 genera). Kondisi sebaliknya ditemukan pada pada kedalaman $10 \mathrm{~m}$ jumlah genera karang di Pulau Barranglompo (29 genera) lebih tinggi dibandingkan dengan Pulau Bonebatang (27 genera). Genera yang paling umum ditemukan pada kedalaman $3 \mathrm{~m}$ di Barranglompo yaitu Acropora, Fungia,dan Porites. Sedangkan di Pulau Bonebatang ditemukan pada genera Ctenactis, Fungia, Pachyseris danPorites. Pada kedalaman $10 \mathrm{~m}$, genera karang yang paling dominan di Pulau Barranglompo adalah Acropora dan Fungia. Sedangkan di Pulau Bonebatang didominasi olehAcropora, Fungia, dan Seriatopora. Dampak antropogenik di Pulau Barranglompo didominasi oleh pembuangan sampah sedangkan Pulau Bonebatang dipengaruhi oleh aktifitas pengeboman ikan.
\end{abstract}

Kata Kunci: Genera Karang, Coral Finder Pulau Barranglompo, Pulau Bonebatang, Spermonde.

\begin{abstract}
The research about "Hard Coral Genera in Barranglompo and Bonebatang Island based on Coral Finder Identification method was conducted from January to April 2016. This study aimed to determine genera diversities of hard corals in the Barranglompo and Bonebatang island. The data was obtained using Line Intercept Transect (LIT) method in the south, west, and north at by a depth of 3 meters and 10 meter, respectively. Coral genera were determined by Coral Finder identification. The results howed the coral genera at a depth of 3 meters were more diverse in Bonebatang island (31 genera) than in Barranglompo island (24 genera). Whereas, the opposite result was found at a depth of 10 meters. Genera diversities of hard corals in Barranglompo island (29 genera) were higher than genera in Bonebatang island (27 genera). The most common genera identified at a depth of 3 meters were Acropora, Fungia, and Porites in Barranglompo island while in Bonebatang island were Ctenactis, Fungia, Pachyseris and Porites. At a depth of 10 meters, the most dominant genera in Barranglompo island were Acropora and Fungia while in Bonebatang island were dominated by Acropora, Fungia, and Seriatopora. Anthropogenic impacts in Barranglompo island were also observed and the garbage is great problem and illegal fishing (Dinamyte) in Bonebatang island.

Keywords: Coral Genera, Coral Finder, Barranglompo island, Bonebatang island, Spermonde.
\end{abstract}




\section{Pendahuluan}

Kepulauan Spermonde adalah merupakan salah satu wilayah penyebaran terumbu karang yang cukup luas. Jumlah pulaunya sekitar 120 pulau dengan luas sekitar 150 km² (Moka, 1995). Permasalahannya sekarang ini adalah potensi tersebut banyak mengalami kerusakan akibat pemanfaatan yang tidak terkendali oleh manusia/masyarakat yang ada disekitarnya. Oleh karena itu diperlukan suatu upaya untuk meminimasi kerusakan tersebut dari pemanfaatan yang tidak ramah ingkungan ke pemanfaatan yang menganut kaidah-kaidah pelestarian, sehingga sumberdaya terumbu karang tersebut dapat dimanfaatkan secara berkelanjutan (Rauf, dan Yusuf, 2004).

Studi yang dilakukan Pet-Soede (2000) menjelaskan bahwa sekitar 2,83\% dari 7.569 kapal yang beroperasi di Spermonde menggunakan alat tangkap ilegal dan dari jumlah itu sekitar $86,5 \%$ menggunakan bahan peledak dan sekitar 10,8\% menggunakan bahan sianida. Tercatat sebanyak $40 \%$ pendapatan dari penangkapan ikan merusak di kepulauan Spermonde berasal dari pemboman dan pembiusan ikan. Penggunaan bom, yang telah berlangsung sejak masa perang dunia II, merupakan bencana besar bagi terumbu karang (Destructive Fishing Watch, 2003).

Ekosistem terumbu karang merupakan sumberdaya wilayah pesisir yang sangat rentan terhadap kerusakan, terutama yang disebabkan oleh perilaku manusia/masyarakat disekitarnya. Oleh karena itu pemanfaatannya harus dilakukan secara ekstra hati-hati. Apabila terumbu karang mengalami kematian (rusak) maka akan membutuhkan waktu yang sangat lama untuk dapat pulih kembali. Menurut Nybakken (1988), beberapa jenis terumbu karang membutuhkan waktu satu tahun untuk mencapai panjang $1 \mathrm{~cm}$

Kondisi perairan dan variasi substrat dapat menjadi faktor pembatas bagi kehadiran jenis-jenis karang batu pada suatu lokasi tertentu. Perairan yang dinamis (berombak) dan atau berarus memiliki keuntungan bagi pertumbuhan karang, seperti ketersediaan kandungan oksigen yang lebih baik dibandingkan perairan tenang. Saat terjadi ombak banyak oksigen yang diikat dan terakumulasi dalam kolom air dan pencucian dengan mudah terjadi pada permukaan karang. Nybakken (1988) menyatakan umumnya terumbu karang tumbuh lebih berkembang pada daerah-daerah yang mengalami gelombang besar. Pada saat yang sama gelombang-gelombang itu memberikan sumber air yang segar, memberikan oksigen dalam air laut dan menghalangi pengendapan pada koloni. Selanjunya Verwey dalam Sukarno et al. (1981) menyatakan arus sangat diperlukan dalam mensuplai oksigen yang cukup bagi fauna di terumbu karang, sebaliknya arus yang tidak terlalu kuat akan mempengaruhi perumbuhan karang batu sehingga pertumbuhannya menjadi lambat (Manuputty, 2012).

Pulau Barrang Lompo dan Bone Batang terletak di zona dua pada jajaran spermonde. Padatnya penduduk pada Pulau Barrang Lompo dapat memberikan pengaruh terhadap kondisi biota khususnya keragaman genera karang yang ada di perairan tersebut. Sedangkan letak Pulau Bone Batang yang tidak berpenduduk, diperkirakan bahwa pengaruh aktifitas penduduk terhadap ekosistem terumbu karang sama sekali tidak ada atau kecil pengaruhnya, utamanya pada genera karang tersebut. 
Identifikasi karang bertahun - tahun telah di lakukan, namun hingga masa sekarang tetap menjadi satu masalah yang bisa digolongkan sangat sulit pemecahannya. Genera merupakan bentuk jamak dari genus dalam pengelompokan hierarki tingkatnya diatas spesies. Menurut (Kelley, 2015) identifikasi karang hingga tingkat spesies hanya dapat dilakukan oleh orang-orang yang ahli dibidang tersebut. Terbitnya buku Coral of The World merupakan satu kemudahan dalam mengidentifikasi karang. Meskipun buku tersebut telah terbit namun identifikasi karang tetap masih sulit dikarenakan kita tidak mungkin membawa ketiga jilid buku tersebut kedalam air. Coral Finder Toolkit 2.0 adalah sebuah metode identifikasi karang keras tingkat genera yang diterbitkan oleh Russel Kelley yang diadopsi dari Buku Coral Of The World. Metode tersebut merupakan jembatan yang menghubungkan antara buku Coral Of The World dengan sistem determinan, dengan karang yang hidup dilaut. Metode tersebut sangat praktis karena buku identifikasi yang digunakan didesain tahan terhadap air (Water Resist). Hadirnya metode Coral Finder ini menjadikan identifikasi hingga tingkat genera bisa dilakukan oleh orang ahli maupun orang pemula. Atas dasar perbandingan kondisi kedua pulau tersebut tersebut dan Metode Coral Finder Toolkit yang lebih memudahkan identifikasi tingkat genera, maka dilakukanlah pengamatan terhadap kondisi keragaman genera karang di Pulau Barrang Lompo dan Pulau Bone Batang.

\section{Bahan dan Metode}

\section{A. Alat}

Alat yang digunakan pada penelitian ini yaitu Roll Meter 100 meter yang digunakan untuk mengukur panjang transek, Alat Dasar (Fins, Masker dan snorkel), Alat Scuba Diving digunakan untuk membantu dalam penyelaman, sabak dan pensil sebagai alat mencatat data, camera bawah air digunakan untuk dokumentasi, perahu untuk transportasi, handfraktometer/salinometer digunakan untuk mengukur salinitas, $\mathrm{pH}$ meter untuk mengukur kadar $\mathrm{pH}$ air, GPS digunakan untuk menentukan lokasi stasiun penelitian, thermometer untuk mengukur suhu, Kaca pembesar untuk mengamati kerangka karang yang tergolong agak kecil, Program Ms. Excel untuk analisis data, Coral Finder Toolkit sebagai alat/buku identifikasi Karang serta buku Coral Of The World.

\section{B. Pengambilan Data dan Identifikasi Karang}

Pengambilan data karang menggunakan metode LIT (Line Intercept Transect) (Gambar 1). Meteran Sepanjang 100 meter dibentangkan pada tiap stasiun Utara, Barat dan Selatan Pulau Barrang Lompo dan Bone Btang, dimana pengambilan sampel dilakukan pada kedalaman $3 \mathrm{~m}$ dan $10 \mathrm{M}$ masing - masing satu kali pengambilan data, yang sejajar dengan garis pantai. Sepanjang $100 \mathrm{M}$, semua koloni karang keras yang dilalui oleh garis transek akan diidentifikasi dan dicatat. Identifikasi dilakukan dengan menggunakan Sistem Coral Finder Toolkit 2.0. Koloni karang keras diidentifikasi dengan cara cepat dan praktis sesuai sistem yang digunakan oleh Coral Finder Toolkit. Bentuk rangka pada karang serta bentuk polip akan menjadi objek utama dalam mengidentifikasi genus Karang Keras. Tiap station dimana pengambilan sampel dilakukan pada kedalaman $3 \mathrm{~m}$ dan $10 \mathrm{~m}$. 


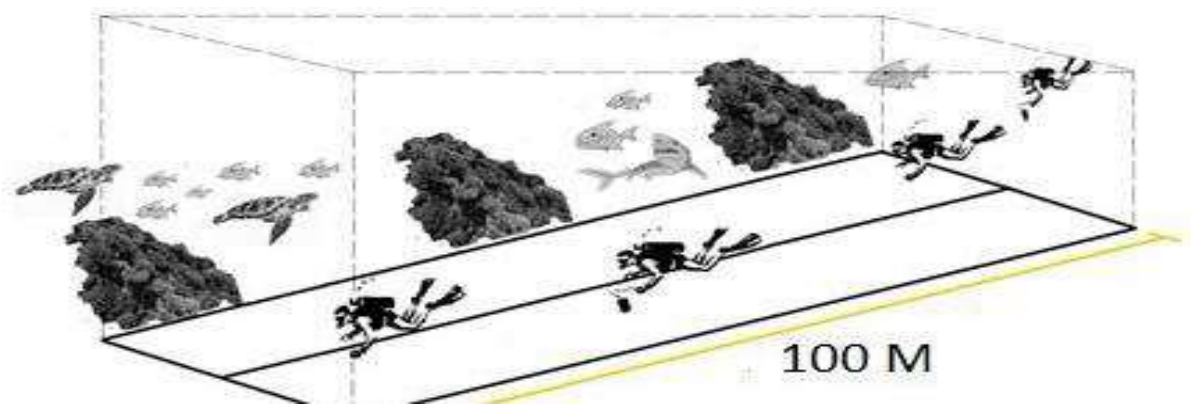

Gambar 1. pengukuran metode LIT. Pengamatan genera karang transek $100 \mathrm{M}$ (English et al., 1997).

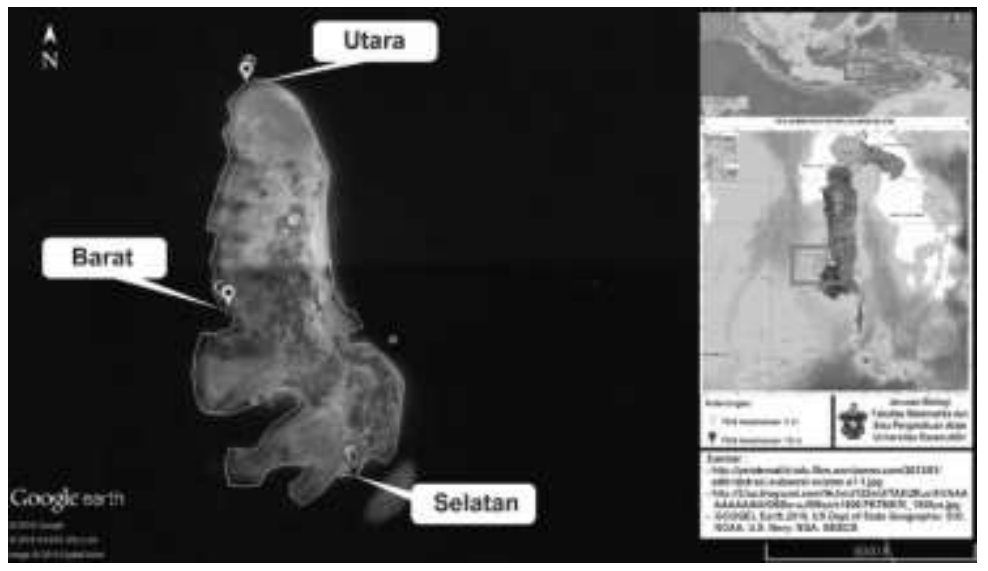

Gambar 2. Lokasi Sampling Pulau Bone Batang

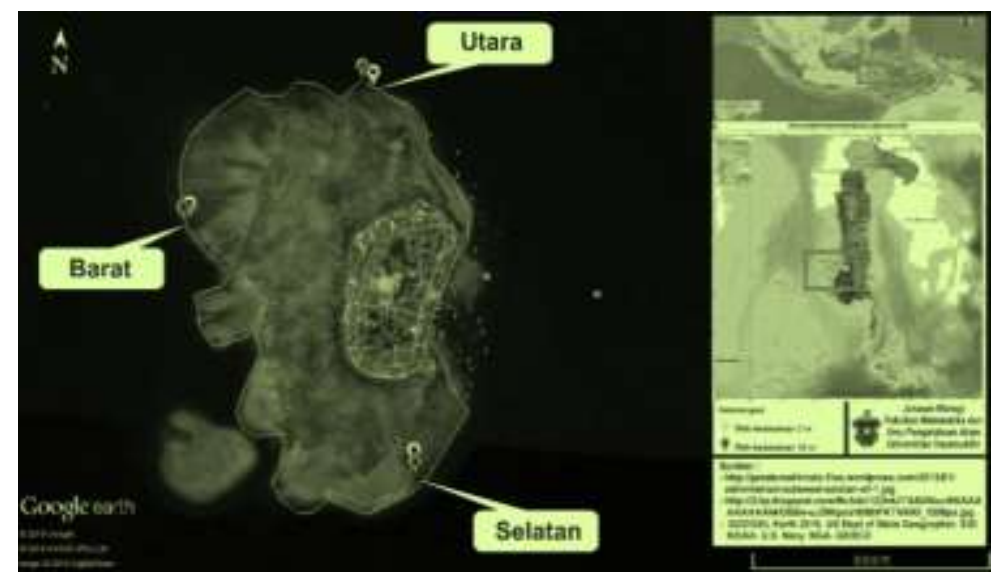

Gambar 2. Lokasi Sampling Pulau Barrang Lompo 


\section{Determinan Identifikasi Coral Finder}

Untuk sistem penggunaan buku identifikasi Coral Finder Toolkit menggunakan sistem determinan dengan contoh sebagai berikut:
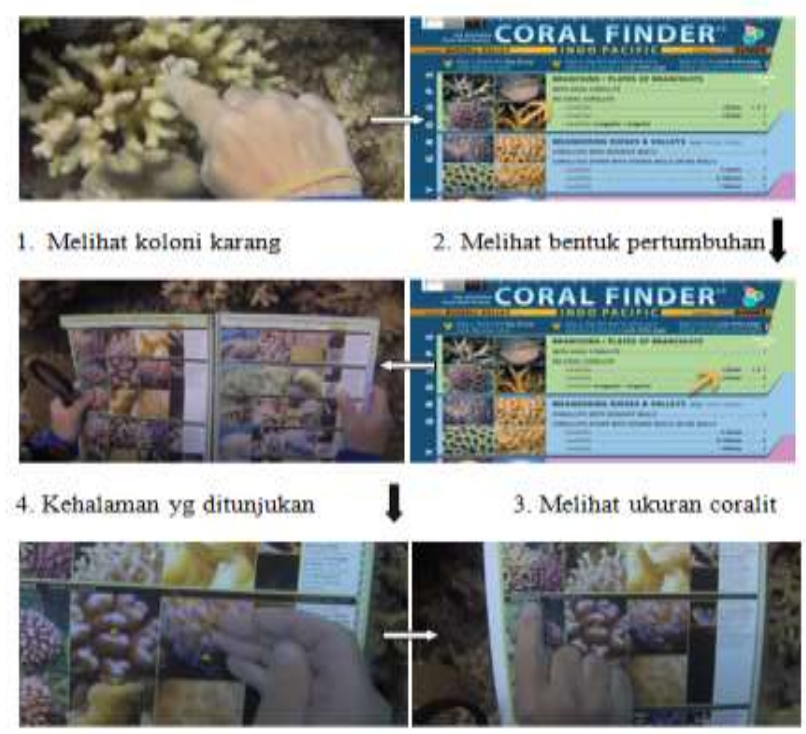

5. Mencocokkan deskripsi serta bentuk.

6. Menemukan genera tersebut.

Gambar 4. Determinan Identifikasi Coral Finder

\section{Hasil dan Pembahasan}

\section{A. Hasil}

Hasil pengambilan data dengan menggunakan metode Line Transect dapat dilihat pada (gambar 5):

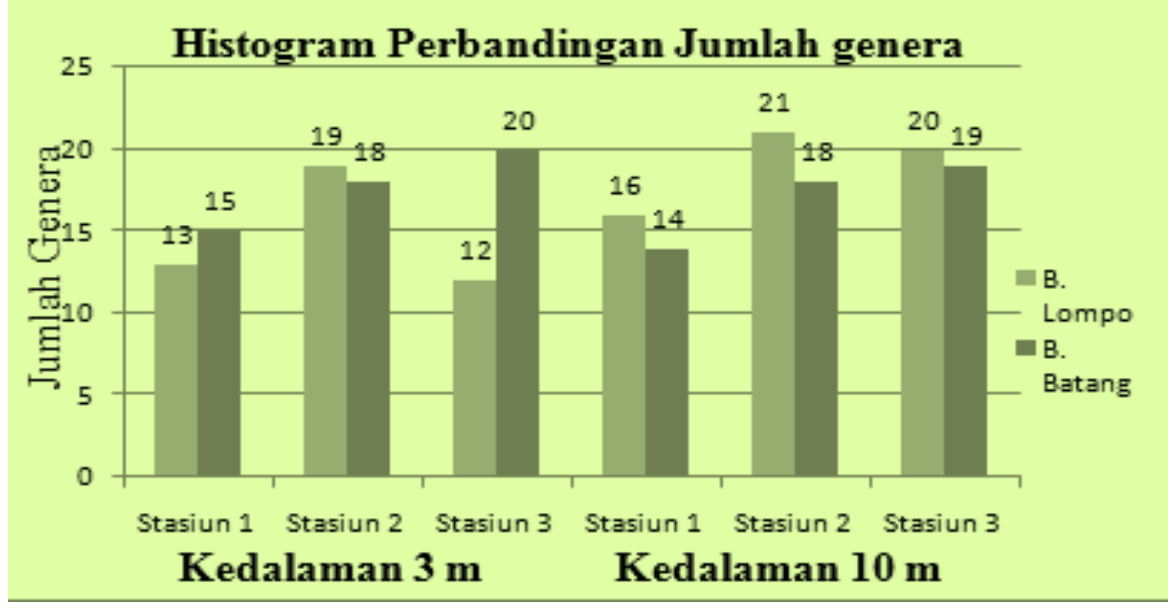

Gambar 5. Histogram Perbandingan Jumlah Genera Tiap Stasiun Di Pulau Barrang Lompo dan Pulau Bone Batang. 
Hasil diperoleh total genera yaitu 37 genera, yang terdiri dari 31 genera di pulau barrang lompo dan 36 genera dipulau bone batang. Genera yang ditemukan tiap - tiap stasiun bervariasi. Pada pulau barrang lompo dengan kedalaman $3 \mathrm{~m}$ jumlah genera yang ditemukan antara 12 - 19, dan pulau barrang lompo kedalaman $10 \mathrm{~m}$ jumlah genera yang ditemukan berkisar antara 16 - 21. Sedangkan untuk pulau bone batang kedalaman $3 \mathrm{~m}$ jumlah genera antara 15 - 20 den kedalaman 10 m yaitu $14-19$ genera.

\section{B. Dampak Aktifitas Manusia}

\section{a. Pulau Barrang Lompo}

Pulau barrang lompo diketahui memiliki penduduk yang padat, sehingga aktifitas manusia sangatlah berpengaruh. Pada bagian selatan tercatat kerusakan akibat sampah sangat tinggi. Sementara bagian barat kedalaman $3 \mathrm{~m}$ tidak ditemukan kerusakan, dan untuk kedalaman $10 \mathrm{~m}$ tercatat kerusakan akibat jangkar, bom, dan penyebab lainnya seperti bius, patahan karang akibat terinjak tergolong rendah. Untuk bagian utara kedalaman $3 \mathrm{~m}$ kerusakan akibat bahan peledak dan sampah tercatat sedikit atau rendah, dan kedalaman $10 \mathrm{~m}$ tidak ditemukan kerusakan. Bila dilihat dari keseluruhan stasiun umumnya sampah menjadi ancaman terhadap karang diPulau Barrang Lompo. Menurut Nobu (2015) bahwa karang dengan pertumbuhan bercabang (branching) lebih sensitif terhadap sampah dibandingkan dengan karang jenis Foliose. Karang jenis bercabang distasiun 1 baik $3 \mathrm{~m}$ maupun $10 \mathrm{~m}$ hanya ditemukan sedikit sementara yang mendominasi yaitu Porites dan Fungia. Porites yang ditemukan umumnya memiliki bentuk pertumbuhan massive. Bentuk pertumbuhan bercabang sangat sensitif dengan sampah dikarenakan sampah yang akan tertahan pada koloni karang, sementara pada bentuk massive tidak memiliki cabang yang panjang sehingga sampah yang terbawa arus akan lewat.

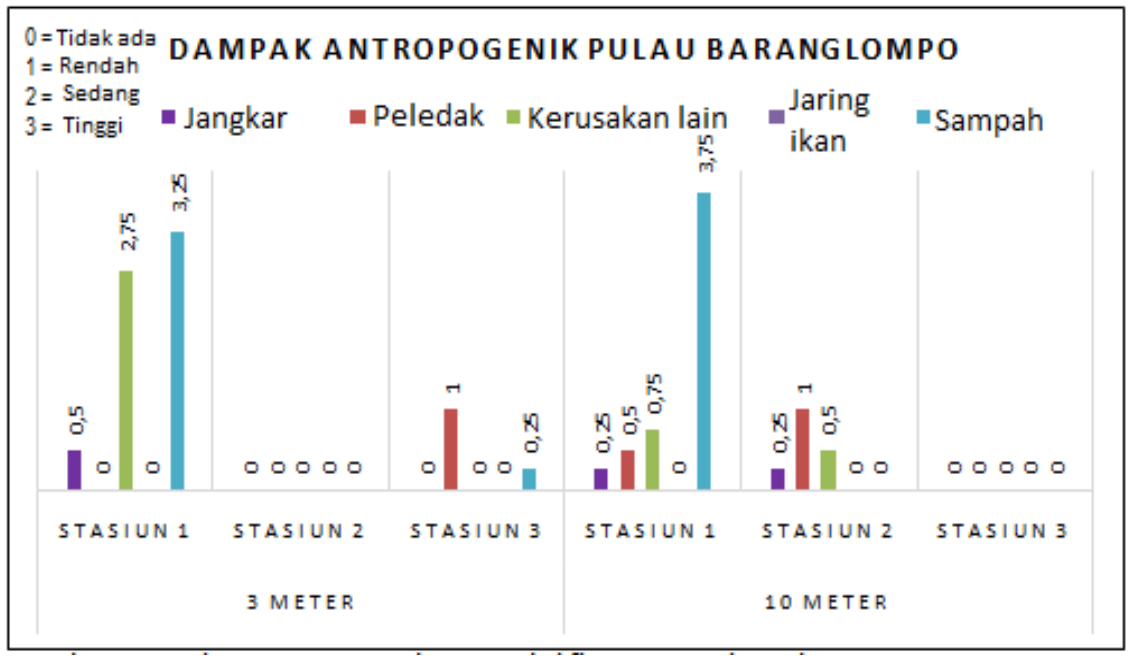

Gambar 7. Histogram Pengukuran Aktifitas Manusia Pulau Barrang Lompo

\section{b. Pulau Bone Batang}

Pulau bone batang diketahui tidak memiliki penduduk, sehingga jelas bahwa dampak aktifitas manusia sangat sedikit. Pada pengambilan data bagian selatan 
kedalaman $3 \mathrm{~m}$ tercatat kerusakan akibat jangkar tergolong rendah, kerusakan akibat peledak dan kerusakan lain seperti bius, patahan karang akibat terinjak tergolong sangat tinggi. sementara pada kedalaman $10 \mathrm{~m}$ tercatat kerusakan akibat bom dan kerusakan lain tergolong tinggi. Pada bagian barat disemua kedalaman kerusakan akibat bom tergolong tinggi dan jaring ikan tergolong rendah. Sementara pada bagian utara kedalaman $3 \mathrm{~m}$ tercatat kerusakan akibat bom tergolong tinggi, kerusakan akibat jaring ikan dan sampah tercatat rendah. Untuk kedalaman $10 \mathrm{~m}$ bom tercatat sangat tinggi sementara sampah tergolong sedang. Dari semua stasiun di Pulau Bone Batang ancaman bom tercatat sangat tinggi. Meskipun Pulau Bone Batang termasuk pulau yang tidak berpenghuni, namun didapatkan data bahwa kerusakan akibat aktifitas manusia dipulau ini lebih tinggi dibandingkan Barrang Lompo. ditemukannya kerusakan akibat bom sangat berpengaruh terhadap jenis karang yang mendominasi area tersebut. Rable merupakan patahan karang akibat ledakan bom yang menutupi sedimen. Menurut Mampuk Dkk (2013) menyatakan bahwa habitat utama Fungia pada pecahan karang. Bila dilihat pada Pulau Bone Batang Fungia merupakan genera yang paling dominan, sehingga dengan adanya kerusakan akibat bom sangat berhubungan dengan keadaan pulau ini.

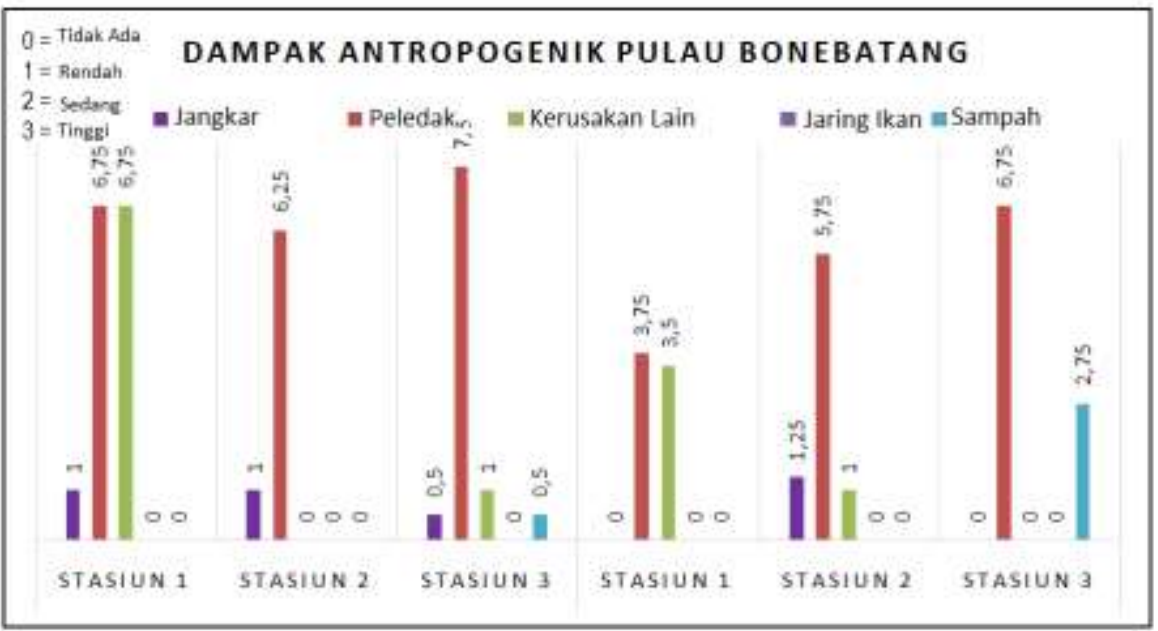

Gambar 8. Histogram Pengukuran Aktifitas Manusia Pulau Bone Batang

\section{C . Sebaran Dan Kelimpahan Koloni Genera Karang Keras}

a. Kedalaman $3 \mathrm{~m}$.

Hasil pengamatn transek pada kedalaman $3 \mathrm{~m}$ di pulau barrang lompo tercatat genera karang yang paling melimpah ditemukan pada Acropora, Fungia, dan Porites. Acropora merupakan karang bercabang (Branching) yang umum ditemukan di kepulauan spermonde utamanya pada kedalaman $3 \mathrm{~m}$. Pada kedalaman $3 \mathrm{~m}$ dengan kecerahan berkisar antara 12,5 - 18,5 m menyebabkan karang jenis Acropora dapat tumbuh dengan baik. Apabila dilihat intensitas cahaya pada kedalaman ini cukup bai. Hal ini sesuai dengan teori menurut Boaden dan Seed (1985) bahwa cahaya matahari yang cukup diperlukan untuk proses fotosintesis zooxanthellae. Selain itu Suharsono (2008) mengatakan bahwa karang dari suku Acroporidae sangat umum dijumpai 
BIOMA : JURNAL BIOLOGI MAKASSAR , 2(2) : 39-51, 2017

diseluruh perairan Indonesia. Komposisi dan sebaran genera karang keras tertera pada tabel 1.

Tabel 1. Perbandingan Frekuensi Genera Karang Keras Kedalaman 3 m.

\begin{tabular}{|c|c|c|c|c|c|c|c|}
\hline \multirow{3}{*}{ No } & \multirow{3}{*}{ Genera Karang } & \multicolumn{6}{|c|}{ Frekuensi Genera Karang } \\
\hline & & \multicolumn{3}{|c|}{ Pulau Barrang Lompo } & \multicolumn{3}{|c|}{ Pulau Bone Batang } \\
\hline & & $\begin{array}{l}\text { Stasium } \\
1\end{array}$ & $\begin{array}{l}\text { Stasium } \\
2\end{array}$ & $\begin{array}{l}\text { Stasium } \\
3\end{array}$ & $\begin{array}{l}\text { Stasium } \\
1\end{array}$ & $\begin{array}{l}\text { Stasium } \\
2\end{array}$ & $\begin{array}{l}\text { Stasium } \\
3\end{array}$ \\
\hline 1 & Acropora & 14 & 80 & 23 & 15 & 1 & 11 \\
\hline 2 & Astreopora & 0 & 2 & 0 & 0 & 0 & 1 \\
\hline 3 & Coeloseris & 0 & 1 & 0 & 1 & 1 & 0 \\
\hline 4 & Ctenactis & 8 & 3 & 0 & 7 & 37 & 1 \\
\hline 5 & Echinopora & 3 & 3 & 0 & 7 & 11 & 2 \\
\hline 6 & Euphyllia & 2 & 0 & 1 & 0 & 1 & 0 \\
\hline 7 & Favia & 7 & 0 & 4 & 1 & 0 & 1 \\
\hline 8 & Favites & 1 & 1 & 1 & 6 & 0 & 14 \\
\hline 9 & Fungia & 59 & 53 & 11 & 9 & 244 & 7 \\
\hline 10 & Galaxea & 0 & 11 & 0 & 1 & 2 & 4 \\
\hline 11 & Goniastrea & 1 & 2 & o & 1 & 0 & 3 \\
\hline 12 & Goniophora & 0 & 0 & 0 & 0 & 0 & 1 \\
\hline 13 & Herpolitha & 0 & 1 & 1 & 1 & 4 & 1 \\
\hline 14 & Leptoseris & 0 & 0 & 0 & 0 & 5 & 0 \\
\hline 15 & Millepora & 0 & 0 & 0 & 0 & 1 & 0 \\
\hline 16 & Montastrea & 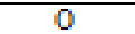 & 0 & 1 & 0 & 0 & 0 \\
\hline 17 & Montipora & 0 & 3 & 2 & 0 & 0 & 6 \\
\hline 18 & Mycedium & 0 & 2 & 0 & 0 & 1 & 0 \\
\hline 19 & Oulophylia & 0 & 0 & 1 & 0 & 0 & 1 \\
\hline 20 & Pachyseris & 1 & 0 & 0 & 0 & 28 & 0 \\
\hline 21 & Pavona & 0 & 0 & 0 & 1 & 17 & 3 \\
\hline 22 & Pectinia & 0 & 2 & 0 & 0 & 2 & 0 \\
\hline 23 & Platygira & 3 & 2 & 0 & 0 & 0 & 5 \\
\hline 24 & Pocillopora & 0 & 9 & 0 & 1 & 0 & 29 \\
\hline 25 & Porites & 26 & 14 & 28 & 13 & 10 & 35 \\
\hline 26 & Psammocora & 0 & 0 & 0 & 2 & 1 & 1 \\
\hline 27 & Seriatophora & 1 & 23 & 0 & 3 & 8 & 6 \\
\hline 28 & Stylophora & 0 & 5 & 0 & 0 & 0 & 0 \\
\hline 29 & Sympyllia & 0 & 0 & 0 & 0 & 1 & 0 \\
\hline 30 & Turbinaria & 0 & 4 & 0 & 0 & 10 & 1 \\
\hline & jumlah & 126 & 221 & 73 & 69 & 385 & 133 \\
\hline & jumlah Genera & & & & & & \\
\hline
\end{tabular}

Pengamatan terhadap aktifitas manusia di stasiun ini menunjukan bahwa sampah menjadi ancaman terhadap pertumbuhan karang di pulau Barrang Lompo. Hasil penelitian Nobu (2015) menunjukkan bahwa ketika sampah anorganik menutupi karang maka cahaya yang masuk akan susah diterima oleh karang karena adanya sampah anorganik yang menghalangi masuknya cahaya matahari. Sehingga zooxanthellae yang ada pada karang tidak lagi mampu berfotositesis untuk membuat cadangan makanan bagi karang.

Sedangkan hasil pengamatan transek di pulau Bone Batang dengan kedalaman 3 $\mathrm{m}$, tercatat genera yang paling melimpah ditemukan pada Ctenactis, Fungia dan Porites. Fungia dan Ctenactis merupakan karang soliter yang hidup bebas di dasar perairan. Karang jenis ini tergolong dalam famili Fungidae. Penelitian yang pernah dilakukan Haerul (2013) bahwa karang Fungidae ditemukan mendominasi di pulau Sarappo Lompo kepulauan Spermonde. Pada kedalaman $3 \mathrm{~m}$ dengan kecerahan berkisar antara 12,5 $17,5 \mathrm{~m}$, menjadi faktor pertumbuhan karang keras utamanya dari jenis Fungidae.

Pengamatan terhadap aktifitas manusia di stasiun ini menunjukan bahwa dipulau Bone Batang, selain sampah, bom menjadi ancaman terbesar terhadap karang. Menurut Mampuk dkk (2013) bahwa keberadaan karang Fungia dalam ekosistem terumbu karang 
juga dapat memberikan informasi tentang keadaan ekosistem tersebut, dimana jika karang jenis ini melimpah, mengindikasikan ekosistem tersebut sebelumnya mengalami kerusakan. Dari teori diatas dapat dibuktikan dengan didapatkannya karang genus Fungia yang hidup baik pada patahan - patahan karang akibat bom.

\section{b. kedalaman $10 \mathrm{~m}$.}

Komposisi dan sebaran genera karang keras tertera pada tabel 1.

Tabel 2. Perbandingan Frekuensi Genera Karang Keras Kedalaman $10 \mathrm{~m}$.

\begin{tabular}{|c|c|c|c|c|c|c|c|}
\hline \multirow{3}{*}{ No } & \multirow{3}{*}{ Genera Karang } & \multicolumn{6}{|c|}{ Frekuensi Genera Karang } \\
\hline & & \multicolumn{3}{|c|}{ Pulau Barrang Lompo } & \multicolumn{3}{|c|}{ Pulau Bone Batang } \\
\hline & & $\begin{array}{l}\text { Stasium } \\
1\end{array}$ & $\begin{array}{l}\text { Stasium } \\
2\end{array}$ & $\begin{array}{l}\text { Stasium } \\
3\end{array}$ & $\begin{array}{l}\text { Stasium } \\
1\end{array}$ & $\begin{array}{l}\text { Stasium } \\
2\end{array}$ & $\begin{array}{l}\text { Stasium } \\
3\end{array}$ \\
\hline 1 & Acropora & 1 & 20 & 10 & 0 & 25 & 1 \\
\hline 2 & Anacropora & 0 & 0 & 2 & 0 & 4 & 0 \\
\hline 3 & Astreopora & 0 & 0 & 0 & 0 & 1 & 2 \\
\hline 4 & Coeloseris & 3 & 0 & 4 & 0 & 0 & 0 \\
\hline 5 & Ctenactis & 0 & 0 & 1 & 0 & 11 & 0 \\
\hline 6 & Echinophyllia & 0 & 3 & 0 & 1 & 0 & 0 \\
\hline 7 & Echinopora & 1 & 6 & 2 & 1 & 0 & 4 \\
\hline 8 & Euphyllia & 0 & 1 & 4 & 0 & 0 & 0 \\
\hline 9 & Favia & 4 & 2 & 13 & 4 & 3 & 3 \\
\hline 10 & Favites & 0 & 1 & 6 & 3 & 2 & 5 \\
\hline 11 & Fungia & 10 & 16 & 7 & 8 & 53 & 1 \\
\hline 12 & Galaxea & 0 & 1 & 4 & 1 & 10 & 7 \\
\hline 13 & Goniastrea & 5 & 0 & 1 & 1 & 0 & 1 \\
\hline 14 & Herpolitha & 0 & 6 & 3 & 0 & 0 & 0 \\
\hline 15 & Leptastrea & 4 & 0 & 0 & 1 & 0 & 0 \\
\hline 16 & Leptoria & 1 & 0 & 0 & 0 & 0 & 0 \\
\hline 17 & Leptosheris & 0 & 0 & 0 & 0 & 2 & 0 \\
\hline 18 & Lobophylia & 4 & 0 & 5 & 2 & 0 & 3 \\
\hline 19 & Montipora & 0 & 2 & 0 & 0 & 15 & 0 \\
\hline 20 & Mycedium & 1 & 1 & 0 & 1 & 0 & 0 \\
\hline 21 & Oulophylia & 0 & 0 & 1 & 0 & 0 & 1 \\
\hline 22 & Oxyphora & 0 & 2 & 0 & 0 & 0 & 0 \\
\hline 23 & Pachyseris & 1 & 4 & 3 & 0 & 2 & 2 \\
\hline 24 & Pavona & 0 & 0 & 0 & 3 & 10 & 2 \\
\hline 25 & Pectinia & 1 & 2 & 1 & 0 & 0 & 0 \\
\hline 26 & Platygira & 2 & 2 & 4 & 0 & 1 & 2 \\
\hline 27 & Pocillopora & 0 & 2 & 0 & 0 & 3 & 1 \\
\hline 28 & Porites & 1 & 8 & 12 & 7 & 14 & 10 \\
\hline 29 & Psammocora & 0 & 0 & 1 & 0 & 0 & 1 \\
\hline 30 & Sandalolitha & 0 & 3 & 2 & 0 & 0 & 0 \\
\hline 31 & Seriatophora & 0 & 1 & 0 & 0 & 57 & 0 \\
\hline 32 & Simphyllia & 0 & 2 & 0 & 1 & 0 & 0 \\
\hline 33 & Stylophora & 1 & 0 & 0 & 0 & 1 & 0 \\
\hline 34 & Turbinaria & 1 & 1 & 0 & 1 & 8 & 6 \\
\hline & JUMIAH & 41 & 86 & 86 & 35 & 222 & 52 \\
\hline
\end{tabular}

Dari hasil pengamatan menggunakan metode transek kedalaman $10 \mathrm{~m}$ Pulau Barrang Lompo tercatat genera karang yang paling melimpah yaitu Acropora dan Fungia. Acropora merupakan jenis karang yang menyukai perairan dangkal yang jernih, selain itu karang Acropora merupakan genus yang dominan diperairan indonesia. Seperti dikatakan oleh Abdul dkk (2003) bahwa genus karang Acropora merupakan karang yang dominan dan habitat karang ini yaitu pada Reef slope serta perairan jernih. Bila dilihat pada perairan Pulau Barrang Lompo dengan kecerahan antara 12,5 - 18,5 m. Untuk kedalaman $10 \mathrm{~m}$ dengan kecerahan tersebut sangat mendukung pertumbuhan karang utamanya Acropora. Selain Acropora ditemukan juga karang jenis lain yaitu Fungia yang hidup dengan baik pada perairan tersebut. 
Pengamatan terhadap aktifitas manusia pada Pulau Barrang Lompo menunjukan bahwa sampah menjadi ancaman terhadap kehidupan terumbu karang di Pulau Barrang Lompo. Menurut penelitian Haerul (2013) Berdasarkan perlakuan jenis sampah anorganik pada karang branching dapat dinyatakan bahwa jenis sampah anorganik selain jaring memberikan dampak buruk terhadap kesehatan karang branching nyata dengan terjadinya pemutihan karang (bleaching). Hal ini diakibatkan oleh intensitas cahaya yang diterima polip karang sangat sedikit bahkan tidak ada karena dihalangi oleh sampah yang tersangkut. Karang yang tertutupi oleh sampah menyebabkan Zooxanthellae tidak berfotosistesis dengan baik, maka terjadilah bleaching.

Hasil pegamatan transek Pulau Bone Batang kedalaman $10 \mathrm{~m}$ dapat dilihat beberapa genera yang melimpah disetiap stasiun yaitu Acropora, Fungia dan Porites. Kedalaman $10 \mathrm{~m}$ tidak jauh berbeda dengan kedalaman $3 \mathrm{~m}$, genus Porites yang umum dijumpai pada kedalaman $3 \mathrm{~m}$, juga ditemukan pada kedalaman $10 \mathrm{~m}$. Porites merupakan genus karang dengan pertumbuhan massive dan branching yang kokoh yang mampu bertahan hidup pada kondisi yang sedikit ekstrim. Menurut Abdul dkk. (2003) Sebaran dapat ditemukan di seluruh perairan Indonesia. Umum dijumpai di setiap terumbu karang.

Pengamatan terhadap aktifitas manusia distasiun ini menunjukan bahwa bom dan sampah menjadi ancaman terhadap pertumbuhan karang di Pulau Bone Batang. Dampak bom mengakibatkan terjadinya penutupan sedimen dengan pecahan karang. Souhoka (2009) menyatakan bahwa sedimentasi dapat mempengaruhi pertumbuhan karang yaitu dengan cara menutupi permukaan polip sehingga menyebabkan kematian, mengurangi kecerahan perairan yang mengganggu proses fotosintesis. Menurut Mampuk (2013) bahwa keberadaan karang Fungiidae dalam ekosistem terumbu karang juga dapat memberikan informasi tentang keadaan ekosistem tersebut, dimana jika karang jenis ini melimpah, mengindikasikan ekosistem tersebut sebelumnya mengalami kerusakan. Selain itu menurut Hoeksema (2009) menyatakan bahwa dispermonde ditemukan sebanyak 37 spesies jenis karang Mushroom atau Fungia.

\section{Perbandingan Genera Karang Keras Pulau Barrang Lompo Dan Bone Batang}

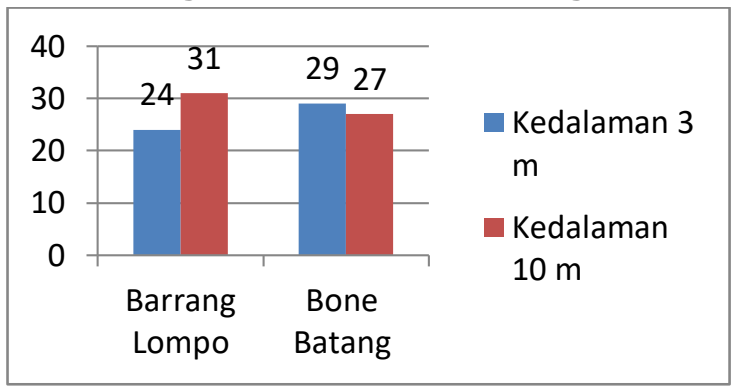

Gambar 9. Histogram Perbandingan Total Genera Kedua Pulau

\section{a. Barrang Lompo Kedalaman $3 \mathrm{~m}$}

Berdasarkan pengambilan data yang telah dilakukan dikedalaman $3 \mathrm{~m}$ pada semua stasiun (1 - 3) Pulau Barrang Lompo, Kec. Ujung Tanah, Makassar, didapatkan Genera karang sebanyak 24 Genera Karang. Genera yang paling mendominasi adalah Acropora yaitu sebanyak 117 Koloni, 14 koloni stasiun 1 (Selatan), 80 koloni stasiun 2 
(Barat), dan 23 koloni stasiun 3 (Utara). Sedangkan genera yang paling sedikit yaitu Coeloseris, Montastrea, Oulophylia, dan Pachyseris. Pachyseris hanya ditemukan 1 koloni pada stasiun 1, Coeloseris ditemukan distasiun 2 sedangkan Montastreadan Oulophylia ditemukan masing - masing 1 koloni ditasiun 3.

\section{b. Bone Batang Kedalaman $3 \mathrm{~m}$.}

Berdasarkan data yang diperoleh di Pulau Bone Batang, Kec. Ujung Tanah, Makassar dengan kedalaman $3 \mathrm{~m}$ stasiun 1 - 3 didapatkan Genera sebanyak 28. Genus yang paling banyak yaitu Fungia sebanyak 260 Individu, 9 Individu stasiun 1 (Selatan), 244 Individu stasiun 2 (Barat), dan 7 Individu stasiun 3 (Utara). Sedangkan Genera yang paling sedikit dijumpai yaitu Euphyllia, Goniophora, Millepora, Mycedium, Oulophylia, dan Symphyllia. Semua genera tersebut masing-masing hanya dtemukan 1 koloni pada salah satu stasiun.

\section{c. Barrang Lompo Kedalaman $10 \mathrm{~m}$.}

Data yang diperoleh menunjukan bahwa jumlah genera karang di Pulau Barrang Lompo dengan kedalaman $10 \mathrm{~m}$ yaitu 16 genera stasiun 1 (selatan), 21 genera stasiun 2 (barat), 20 genera stasiun 3 (utara). Genus yang paling mendominasi pada kedalaman ini adalah Fungia sebanyak 33 Individu, yaitu tercatatsebanyak 10 individu Stasiun 1 (Selatan), 16 individu Stasiun 2 (Barat), dan 7 Individu Stasiun 3 (Utara). Sedangkan genera yang paling sdikit dijumpai adalah Ctenactis, Leptoria, Oulophylia, Psammocora, dan Seriatophora.

\section{d. Bone Batang Kedalaman $10 \mathrm{~m}$}

Pada pengamatan dipulau bone batang dengan kedalaman $10 \mathrm{~m}$ didapatkan sebanyak 27 genera. Genus yang paling banyak yaitu Seriatopora dengan jumlah 57 distasiun barat pulau bone batang. Menurut (Abdul dkk (2003) karang ini menyukai daerah dangkal dan banyak menerima cahaya matahari. Dilihat pada stasiun ini kecerahan mencapai 17,5 m, dan memungkinkan karang ini bisa hidup dengan optimum. Sedangkan untuk genera yang paling sedikit yaitu Echinophyllia, Leptastrea, Mycedium, Oulophylia, Psammocora, Simphyllia.

\section{KESIMPULAN}

Berdasarkan dari hasil dan pembahasan maka kesimpulan yang dapat dikemukakan adalah sebagai berikut :

1. Pada kedalaman $3 \mathrm{~m}$ genera karang yang ditemukan di Pulau Bone Batang ( 31 genera) lebih banyak dibandingkan dengan Pulau Barrang Lompo (24 genera). Kondisi sebaliknya ditemukan pada pada kedalaman $10 \mathrm{~m}$ dengan Jumlah genera karang di Pulau Barrang Lompo (29 genera) lebih tinggi dibandingkan dengan Pulau Bone Batang (27 genera).

2. Genera yang paling umum ditemukan dipulau Barrang Lompo pada kedalaman $3 \mathrm{~m}$ yaitu Acropora, Fungia, dan Porites. Sedangkan di Pulau Bone Batang ditemukan pada genera Ctenactis, Fungia, Pachyseris dan Porites. Untuk kedalaman $10 \mathrm{~m}$, genera karang yang paling dominan di Pulau Barrang Lompo adalah Acropora dan 
Fungia. Sedangkan di Pulau Bone Batang didominasi oleh Acropora, Fungia, dan Seriatopora.

3. Dampak antropogenik di Pulau Barrang Lompo didominasi oleh pembuangan sampah sedangkan Pulau Bone Batang dipengaruhi oleh aktifitas penangkapan ikan tidak ramah lingkungan (Dinamit).

\section{DAFTAR PUSTAKA}

Abdul, K., U., Suryo K., dan Indra W., 2003. Panduan Pengenalan Jenis - jenis Karang Hias Yang Diperdagangkan. Assosiasi Koral dan Ikan Hias Indonesia ( AKKII). Jakarta. Hal 9 - 41

Haerul, 2013. Analisis Keragaman Dan Kondisi Terumbu Karang Di Pulau Sarappolompo, Kab. Pangkep. Skripsi Jurusan Ilmu Kelautan,

Fakultas IImu Kelautan Dan Perikanan Universitas Hasanuddin, Makassar. Hal 37 - 39.

Boaden, P. and R. Seed., 1985. An Introduction to Coastal Ecology. Blackie and Sun Ltd. New York. Hal 18.

Destructive Fishing Watch (DFW), 2003. Laporan : Kajian Cepat (Rapid Assessment) Kegiatan Penangkapan Ikan Tidak Ramah Lingkungan (PITRAL) di Kepulauan Spermonde Sulawesi Selatan. Kerjasama COREMAP dan DFW. Makassar. Sulawesi Selatan. Hal $1-5$.

English, S., C. Wilkinson, and V. Baker. 1997. Survey Manual For Tropical Marine Hal. 48

Hoeksema, W. B., 2009. West-East Variation in the Indonesian Reef Coral Fauna: Lines of Division or Zones of Transition?. National Museum of Natural History Naturalis. Leiden, The Netherlands. Hal 4-7

Kelley, R., 2015. Resources \& Training For Coral Identification. Program Director CICBP - Coral Hub. Australy.

Mampuk, F., H. Tioho., and J. D. Tusen, 2013. Distribusi Vertikal Dan Kepadatan Karang Fungiidae Di Perairan Malalayan. Program Studi IImu Kelautan, Fakultas Perikanan dan Ilmu Kelautan, Universitas Sam Ratulangi, Manado. Jurnal Pesisir dan Laut. Hal $41-44$

Manuputty, A. E. W., 2012. Ekosistem Pesisir Perairan Pangkajene Kepulauan Provinsi Sulawesi Selatan. Pusat penelitian oseanografi LIPI. Jakarta. Hal: 73.

Moka, W., 1995. Bentuk Kepulauan Spermonde $\quad$ (Spermonde). Materi Pendidikan dan Latihan Metodologi Penelitian Penentuan Kondisi

Terumbu Karang. P30 LIPI; UNHAS dan YASINDO. Ujung Pandang. Hal 259

Nobu F., S., 2015. Pengaruh Sampah Anorganik Terhadap Kondisi Karang Keras. Skripsi Jurusan IImu Kelautan, Fakultas IImu Kelautan Dan Perikanan Universitas Hasanuddin, Makassar 
Nybakken I. W., 1988. Biologi Laut Suatu Pendekatan Ekologis. PT. Gramedia Jakarta. Jakarta. Hal 370

Pet-Soede, L., 2000. Options For Co- Management of an Indonesia Coastal Fishery. Wageningen Universiteit. Wageningen. The Netherlands.

Rauf A., dan M. Yusuf, 2004. Studi Distribusi dan Kondisi Terumbu Karang dengan Menggunakan Teknologi Penginderaan Jauh di Kepulauan Spermonde, Sulawesi Selatan, IImu Kelautan. Juni 74- 81. Resources. S econd Edition.Australia Institute of Marine Science. Townsville: $390 \mathrm{p}$.

Souhoka J., 2009. Kondisi Dan Keanekaragaman Jenis Karang Batu Di Pulau Nusalaut, Maluku Tengah. UPT. Loka Konservasi Biota Laut -LIPI, Bitung. Jurnal Perikanan J. Fish. Sci.) XI $\quad$ (1): 54-65

Suharsono. 2008. Jenis - Jenis Karang Diindonesia. Pusat Penelitian Oseanografi LIPI. Jakarta 366 Hal. 